\title{
Long-Term Simulation of the Effect of Low Impact Development for Highly Urbanized Areas on the Hydrologic Cycle in China
}

\author{
Shuai Niu, Lei Cao, Yu Li, and Jinhui Huang
}

\begin{abstract}
For areas that are urbanized rapidly, the practice of Low Impact Development (LID) has gained an important place in stormwater management and urban planning due to its capability and beneficial effects in restoring the original hydrological cycle. The performances of LID alternatives can vary substantially due to different climate conditions. This study investigated the performances of three LID alternatives under a semi-arid climate in northern China on water balance. A numerical model, the storm water management model (SWMM), was employed to run 10 years' rainfall events for these objectives. The efficiency index for water balance (Iw) is also introduced in this study and three LID alternatives are evaluated by using the above methodology. According to the research results, LID facilities have remarkable effects on water balance.
\end{abstract}

Index Terms - Low impact development, urban development, water balance.

\section{INTRODUCTION}

With urban development and the continuously intensified process of urbanization, people's destruction to the ecological system gradually appears. To a large extent, change in urban land usage and increasingly rising ground cementation index prevents rainwater from infiltrating and increases rainfall runoff. This not only results in a waste of water resources but also has great impact on circulation of the water system, causing flood and other disasters. Urban flood disaster, water resource pollution and rainwater resource loss have already become important issues restraining the development of Chinese cities. Research has proved that urbanization is directly correlated with water balance and flood control [1].

At present, LID (low impact development) management system is widely applied by numerous developed countries in the control over water balance and flood [2], [3]. LID is a development philosophy released by America in the 1990s. It is mainly based on the simulation of natural and hydrologic conditions, so as to control water sources and pollution of urban rainfall runoff through small-scale and decentralized LID facilities, finally reduce the urban impermeable rate, make circulation of the water system closer to the state before

Manuscript received January 23, 2015; revised June 1, 2015.

Shuai Niu and Lei Cao are with the Architecture School of Tianjin University, China (e-mail: xiaoxin07067@qq.com, tjdxc12006@163.com).

$\mathrm{Yu} \mathrm{Li}$ is with the State Key Laboratory of Hydraulic Engineering Simulation and Safety, School of Civil Engineering, Tianjin University, China (e-mail: 516571927@qq.com).

Jinhui Huang is with the College of Environmental Science and Engineering of Nankai University, China (e-mail: huangj@tju.edu.cn). urban development, and restore the ecological system to the maximum extent [4], [5].

LID facilities mainly researched in this paper include bio-retention [6], [7], grass swale [8] and porous pavement [9]. These facilities can reduce urban flood and other disasters caused by rainfall runoff. At the same time, these facilities also have good social benefits, ecological benefits and economic benefits. For instance, bio-retention is formed by planting some shrubs and arbors on manually excavated depressions. It can be used to collect rainfall runoff, so as to achieve the effects of reducing runoff, increasing infiltration, and purifying water through permeation and purification functions of soil and plants. Bio-retention has obvious effects on reducing runoff. Moreover, it reduces costs when compared with traditional rainwater management. Moreover, bio-retention has good landscape value. Generally, porous pavement is made of wind-blown sand, argil or cement concrete. It is of certain permeable and water locking function, which can increase the infiltration capacity of ground, absorbing noise, preventing pollution, and alleviating urban heat island effect. This kind of porous pavement is widely applied in open-parking grounds in Europe and some small-sized highways in some cities in England and Sweden.

The storm water management model (SWMM) was developed by U.S. Environmental Protection Agency in the 1970s [10]. SWMM is used to simulate the rainfall runoff of single rainfall event or long-term continuous rainfall runoff. SWMM can be used to load different LID facilities in the research area and set and commission parameters of different facilities, so as to make it convenient for the research on the effects of different LID facilities for water balance and flood control. It is relatively convenient for the comparison of results displayed [11].

\section{MATERIALS AND METHODS}

The direct impact of the progress of urbanization is to change the impermeable rate of city. With the intensified urbanization, the impermeable rate keeps sharply increasing, thus influencing the circulation of urban water system, causing damage to both structure and function of the ecological system, and triggering flood and other natural disasters.

The new campus of Tianjin University is located in Jinnan District of Tianjin Municipality, in the middle of Haihe Education Park between the central urban area of Tianjin and the core area of coastal new-region, and in the west of the ecological green gallery as shown in Fig. 1. The new campus 
covers an area of approximately $2.5 \mathrm{~km}^{2}$. Due to different land usages, it can be divided into the impermeable area and the permeable area. The impermeable area is of buildings, roads and hard pavement plaza, accounting for about $36 \%$ of the total area. Other areas are of greenbelts and water systems. According to the calculation, the impermeable rate of the campus is $40 \%$.

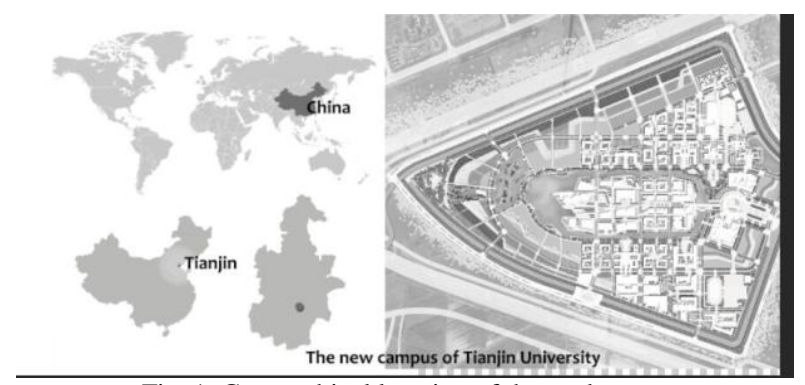

Fig. 1. Geographical location of the study area.

Tianjin belongs to semi-humid continental climate in the warm temperate zone. According to the rainfall data in the past 50 years, yearly average precipitation is approximately $550 \mathrm{~mm}$, but the rainfall time is unevenly distributed. The number of days of rainfall and precipitation are mainly concentrated upon summer. $78.5 \%$ annual rainfall is mainly concentrated in June - August. The flood season appears on the second half month of July and the first half month of August. In terms of rainfall duration, the number of times of rainfall for over 4 hours accounts for more than $75 \%$ of the annual number of times of rainfall. And the average rainfall depth is $13.9 \mathrm{~mm}$ for each rainfall event which duration is less than 4 hours and the average rainfall depth is $27.7 \mathrm{~mm}$ for each rainfall event which duration is more than 4 hours. In this paper, therefore, hourly rainfall data in summer from 2003 to 2012 is taken as typical rainfall in Tianjin. This data is loaded into SWMM for simulation. In total, the number of times of rainfall is 261, including 195 times of rainfall lasting for over 4 hours.

In this research, SWMM5 is used to simulate 261 times of rainfall in the new campus of Tianjin University from 2003 to 2012, so as to analyze and discuss the difference between the traditional rainfall management system and the system added with LID facilities, make a research on the impacts on rainfall runoff and other indexes after separately loading three LID facilities (i.e. bio-retention, grass swale and porous pavement), and further evaluate the performance of the three facilities for water balance and flood control. By combining the retention depth, the efficiency index for water balance $(I w)$ is introduced in this research [12]. This index can reflect the effect of LID facilities in a more visual way.

$$
d=\frac{V}{A}
$$

In which $d$ is the storage in depth, $\mathrm{mm} ; V$ is the total storage volume of the LID practices, $\mathrm{m}^{3} ; A$ is the area of the catchment area, $\mathrm{m}^{2}$.

$$
I w=\frac{R}{d}
$$

In which $I w$ is the efficiency index for water balance, $R$ is the total storage volume of the LID practices, $\mathrm{m}^{3} ; \mathrm{d}$ is the storage in depth, $\mathrm{mm}$.

The utilized methodology for assessing the performances of low impact development alternatives by long-term simulation is presented in Fig. 2.

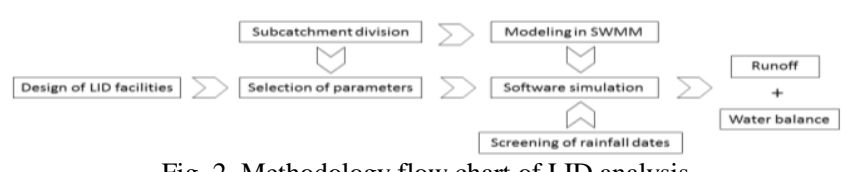

Fig. 2. Methodology flow chart of LID analysis.

TABLE I: The Storage Volume and the Storage DePTh Provided by EACH TYPE OF LID ALTERNATIVE

\begin{tabular}{llll}
\hline \hline & Bio-retention & $\begin{array}{l}\text { Grass } \\
\text { swales }\end{array}$ & Porous pavement \\
\hline $\begin{array}{l}\text { Surface layer }\left(\mathrm{m}^{3}\right) \\
\begin{array}{l}\text { Soil/Pavement } \\
\text { layer }\left(\mathrm{m}^{3}\right)\end{array}\end{array}$ & 17.40 & 1500.00 & 15.00 \\
$\begin{array}{l}\text { Storage layer }\left(\mathrm{m}^{3}\right) \\
\begin{array}{l}\text { Total storage in depth } \\
(\mathrm{d})(\mathrm{mm})\end{array}\end{array}$ & 1102.95 & - & 225.00 \\
\hline \hline
\end{tabular}

TABLE II: CHARACTERISTICS OF THE SELECTED LID FACILITIES

\begin{tabular}{cl}
\hline \hline LID Practice & \multicolumn{1}{c}{ Modeling Parameters } \\
\hline Bio-retention & Thicknesses of the surface and storage \\
& layers were $20 \mathrm{~mm}$ and $500 \mathrm{~mm}$ \\
& respectively \\
& 0.1 for vegetation factor \\
& 0.45 for void ratio \\
& 0.15 for slope \\
\hline Grass swale & $2.5: 1$ for side slope for surface layer \\
& Depth of 500 mm \\
& 0.1 for vegetative cover fraction \\
& Depth of 500 mm for swale layer \\
& 0.3 for surface roughness \\
& Void ratio of 0.45 for the storage layer, \\
& 0.31 for the pavement layer \\
& 0.04 for surface slope \\
& 0.1 for surface roughness \\
& $1.30 \mathrm{~m}$ for bedrock depth from base of \\
Porous pavement & System \\
& fituated 3.1 from building \\
\hline \hline
\end{tabular}

In the SWMM5 model, sub-catchments were delineated by the grading of the site plan and the land use data. Thirty-six sub-catchments were determined with areas ranging from 0.03 to $0.09 \mathrm{~km}^{2}$ by using ArcGIS. Land surface slopes for these sub-catchments were between $0.2 \%$ and $3.9 \%$. Manning's roughness values were set to 0.2 for the pervious surfaces and 0.013 for the impervious surfaces. Depression storages of the pervious and impervious surfaces were set to 2.5 and $1.0 \mathrm{~mm}$, respectively. The slopes and lengths of conduits were provided by the storm sewer network design. The roughness of the conduit was set as 0.013 for circular, concrete pipes. Different LID facilities are planned into specific positions according to the features of different plots in the research area and by combining the scope of application of LID facilities. Considering local hydrologic conditions in Tianjin, the selection principle of LID design parameters is shown as follows: retain water resources as much as possible. In the research, therefore, the LID retention capacity is set as the capacity meeting this amount of rainwater. At the same time, the capacity is set to reduce the impermeable rate, lengthen the runoff path, and cut down rainwater and flood 
peak. In LID facilities, the size of storage of rainwater is mainly decided by the retention function of corresponding LID facilities. For a convenient comparison of the capacity of different facilities, the retention capacity is converted into depth for comparison in this research. The information about the storages provided by these LID alternatives is shown in Table I.

Table II lists the design characteristics of these three LID alternatives selected for the new campus and the associated parameters implemented in the SWMM5 model.

\section{RESULTS AND DISCUSSIONS}

TABLE III: SIMULATING RESULTS FOR RAINFALL EVENTS (DURATION LESS THAN 4 HOURS)

\begin{tabular}{lllll}
\hline \hline $\begin{array}{l}\text { Hydrological } \\
\text { Variables }\end{array}$ & No LID & Bio-retention & $\begin{array}{l}\text { Grass } \\
\text { swale }\end{array}$ & $\begin{array}{l}\text { Porous } \\
\text { pavement }\end{array}$ \\
\hline $\begin{array}{l}\text { Average } \\
\text { runoff(mm) }\end{array}$ & 4.411 & 3.512 & 3.825 & 3.402 \\
$\begin{array}{l}\text { Change of total } \\
\text { runoff(\%) }\end{array}$ & 20.382 & 13.329 & 22.873 \\
$\begin{array}{l}\text { Ratio of runoff to } \\
\text { precipitation }\end{array}$ & 0.317 & 0.253 & 0.275 & 0.245 \\
$\begin{array}{l}\text { Rainfall captured } \\
\text { by LID on } \\
\text { site(mm) }\end{array}$ & 0.899 & 0.586 & 1.009 \\
Iw & 0.048 & 0.036 & 0.044 \\
\hline \hline
\end{tabular}

The effects of each LID implementation on the restoration of hydrological cycle in terms of water balance and peak flow are presented in Table III and Table IV. For rainfall events with short duration(less than 4 hours), the porous pavement provided remarkable reduction in total runoff with a reduction rate of $22.83 \%$, followed by bio-retention of $20.38 \%$. Grass swale had the minimal effect on average runoff with a rate of $13.32 \%$ reduction. In terms of the ratio of runoff to precipitation, among three LID facilities, porous pavement had the best effect by reducing the ratio to 0.245 , while considering the efficiency index for water balance $(I w)$, bio-retention had the best value of 0.048 and porous pavement (0.044) and grass swale $(0.036)$ came in second and third.

TABLE IV: SIMULATING RESULTS FOR RAINFALL EVENTS (DURATION MORE THAN 4 HOURS)

\begin{tabular}{llllc}
\hline $\begin{array}{l}\text { Hydrological } \\
\text { Variables }\end{array}$ & No LID & Bio-retention & $\begin{array}{l}\text { Grass } \\
\text { swale }\end{array}$ & $\begin{array}{c}\text { Porous } \\
\text { pavement }\end{array}$ \\
\hline $\begin{array}{l}\text { Average runoff (mm) } \\
\begin{array}{l}\text { Change of total } \\
\text { runoff(\%) }\end{array}\end{array}$ & 9.091 & 7.598 & 7.967 & 8.345 \\
$\begin{array}{l}\text { Ratio of runoff to } \\
\text { precipitation }\end{array}$ & 0.328 & 0.274 & 12.366 & 8.206 \\
$\begin{array}{l}\text { Rainfall captured by } \\
\text { LID on site(mm) }\end{array}$ & & 1.494 & 0.287 & 0.301 \\
\begin{tabular}{l} 
Iw \\
\hline \hline
\end{tabular} & & 0.080 & 1.124 & 0.747 \\
\hline
\end{tabular}

For rainfall events with long duration (more than 4 hours), it can be seen from TABLE IV that bio-retention functioned significantly in reducing the total runoff, with a reduction rate of $16.42 \%$. The ratio of runoff to precipitation saw an opposite trend and bio-retention had the best effect by reducing the ratio to 0.274 . In terms of the efficiency index for water balance $(I w)$, bio-retention had the best value of 0.080 , followed by grass swale of 0.068 and porous pavement of 0.032 .

\section{CONCLUSIONS}

According to the research results, LID facilities have remarkable effects on lowering rainfall runoff and changing water balance. Moreover, LID facilities have more obvious effects for short-term rainfall. In terms of water balance, bio-retention is of the optimal effect. In terms of flood control, both bio-retention and porous pavement are of good effects. According to the efficiency index for water balance provided by the storage depth and facilities, bio-retention has the most effective retention performance.

Therefore, LID facilities can be vigorously promoted for development and construction of Chinese cities and for reconstruction of old cities. This research provides performance indexes and scope of application of different LID facilities for urban planning constructors. Urban constructors can plan and set different LID facilities according to local conditions, or use in combination, so as to achieve the purpose of urban water balance restoration and flood control. Possible sedimentation and blocking circumstances of LID facilities should also be taken into consideration when SWMM is used to simulate rainfall of long-term sequence. It is recommended to set the performance degradation factor according to actual conditions, so as to have more effective and accurate simulation results. This will also become a significant topic of research.

\section{REFERENCES}

[1] R. Pitt, "Small storm hydrology and why it is important for the design of stormwater control practices," Advances in Modeling the Management of Stormwater Impacts, vol. 7, pp. 61-91, 1999.

[2] C. Damodaram et al., "Simulation of combined best management practices and low impact development for sustainable stormwater management," Journal of the American Water Resources Association, vol. 46, no. 5, pp. 907-918, 2010.

[3] M. E. Dietz and J. C. Clausen, "Stormwater runoff and export changes with development in a traditional and low impact subdivision," Journal of Environmental Management, vol. 87, no. 4, pp. 560-566, 2008 .

[4] A. P. Davis, "Green engineering principles promote low-impact development," Environmental Science and Technology, vol. 39, no. 16, pp. 338A-344A, 2005.

[5] J. C. Guo, G. E. Blackler, T. A. Earles, and K. MacKenzie, "Incentive index developed to evaluate storm-water low-impact designs," Journal of Environmental Engineering, vol. 136, no. 12, pp. 1341-1346, 2010.

[6] R. A. Brown and W. F. Hunt, "Improving bioretention/biofiltration performance with restorative maintenance," Water Science and Technology, vol. 65, no. 2, pp. 361-367, 2012.

[7] W. F. Hunt, A. R. Jarrett, J. T. Smith, and L. J. Sharkey, "Evaluating bioretention hydrology and nutrient removal at three field sites in North Carolina," Journal of Irrigation and Drainage Engineering, vol. 132, no. 6, pp. 600-608, 2006.

[8] M. Bäckström, M. Viklander, and P. A. Malmqvist, "Transport of stormwater pollutants through a roadside grassed swale," Urban Water Journal, vol. 3, no. 2, pp. 55-67, 2006.

[9] B. K. Ferguson, Porous Pavements, Boca Raton, FL: CRC Press, Taylor and Francis Group, 2005.

[10] L. A. Rossman, Storm Water Management Model User's Manual, National Risk Management Research Laboratory, Office of Research and Development, US Environmental Protection Agency, 2010.

[11] A. H. Elliott and S. A. Trowsdale, "A review of models for low impact urban stormwater drainage," Environmental Modelling and Software, vol. 22, no. 3, pp. 394-405, 2007. 
[12] Huang, J. Jeanne, Y. Li, S. Niu, and S. H. Zhou. "Assessing the performances of low impact development alternatives by long-term simulation for a semi-arid area in Tianjin, Northern China," Water Science and Technology, vol. 70, no. 11, pp. 1740-1745, 2014.

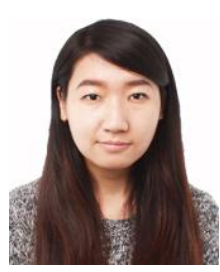

Shuai Niu is an M.Sc student in landscape architecture in Tianjin University. She got a bachelor degree in urban planning from Tianjin Chengiian University, China in 2013. She is an active researcher in the field of eco-hydrology and urban planning.

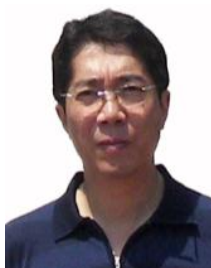

Lei Cao is a Ph.D. holder. He finished his doctor of philosophy degree and the master degree in architecture from Tianjin University. He is a professor of Architecture School of Tianjin University and a director of the Landscape Architecture Institute of Tianjin University Architectural Planning and Design. Since he joined the Landscape Architecture Institute of Tianjin University Architecture School, he has published more than 50 papers in refereed journals. He is also a member of the National Landscape Architecture Master Steering Committee (Ministry of Education).

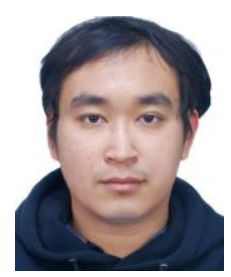

Yu Li is a researcher of the State Key Laboratory of Hydraulic Engineering Simulation and Safety, School of Civil Engineering, Tianjin University. He finished his master degree in water resources from Tianjin University in 2015. He has published three papers in the field of low impact development.

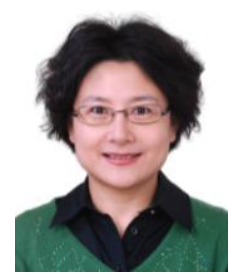

Jinhui Huang is a Ph.D. holder. She finished her doctor of philosophy degree from School of Engineering, University of Guelph, Canada. She is a professor of College of Environmental Science and Engineering of Nankai University and an adjunct professor of University of Guelph, Canada. She is also a fellow of Canadian Society for Civil Engineering. 